\title{
ASSESSMENT OF PROFITABILITY OF WATER MELON (CITRILLUS LANATUS) IN SELECTED MARKETS IN PARTS OF KADUNA NORTHERN GUINEA SAVANNAH OF NIGERIA
}

\author{
Sodimu, A.I. ${ }^{* 1} \boldsymbol{\Xi}$, Usman, M.B. ${ }^{1}$, Oladele, N.O. ${ }^{2}$, Lapkat, L.G. ${ }^{1}$, Awobona, T.A. 1, \\ Suleiman, R. 1 \\ ${ }^{1}$ Federal College of Forestry Mechanization, Forestry Research Institute of Nigeria, P.M.B. 2273, \\ Afaka, Kaduna Nigeria \\ 2 Trial Afforestation Project, Forestry Research Institute of Nigeria, P.M.B.2312, Afaka, Kaduna \\ Nigeria
}

DOI: https://doi.org/10.29121/granthaalayah.v8.i5.2020.78

Article Type: Case Study

Article Citation: Sodimu, A.I., Usman, M.B., Oladele, N.O., Lapkat, L.G., Awobona, T.A. and Suleiman, R. (2020). ASSESSMENT OF PROFITABILITY OF WATER MELON (CITRILLUS LANATUS) IN SELECTED MARKETS IN PARTS OF KADUNA NORTHERN GUINEA SAVANNAH OF NIGERIA. International Journal of Research GRANTHAALAYAH, 8(5), 121-125. https://doi.org/10.29121/granthaa layah.v8.i5.2020.78

Received Date: 12 May 2020

Accepted Date: 29 May 2020

Keywords:

Water Melon

Profitability

Markets

Kaduna Northern Guinea Savanna

\begin{abstract}
The study examines the assessment of profitability of watermelon (Citrillus lanatus) in selected markets in parts of Kaduna Northern Guinea Savanna of Nigeria. One hundred questionnaires were randomly administered (100) and 51 were recovered from the respondents. Descriptive statistics gross margin analysis and Z- test were used to analyze the data collected. The results revealed that $74.51 \%$ of the respondents are male and $25.29 \%$ are female. Majority of the respondents are aged between $35-45$ years (43.14\%) and $12.55 \%$ are married. $35.29 \%$ of the respondent had secondary education and 39.21\% had primary education. The gross margin analysis shows a significant level of profitability at $(P>0.05)$ with estimated net income of $\# 10,851.20$ per annum. The Z- test further shows that the calculated value was statistically significant at $(\mathrm{P}>0.05)$ probability level. However, recommendation for improvement and marketing of the species were highlighted.
\end{abstract}

\section{INTRODUCTION}

Fruits are concentrated source of natural components. These natural components are plant derived materials performing a key role in maintaining human health, especially in disease prevention, growth and development. In the recent era, phyto-nutrients, particularly from fruits and vegetables, are becoming popular due to consumer awareness regarding their health enhancing potential [1] Water melon (Citrullus lanatus Thumb. Matsum and nakai) belongs to the family of Cucurbataceae. It is an important horticultural crop mostly known for its sweet and juicy fruit, grown in warm climates all over the world [2],[3]. In Africa, watermelon accounts for 5.4\% of the harvested

(C) 2020 The Author(s). This is an open access article distributed under the terms of the Creative Commons Attribution License, which permits unrestricted use, distribution, and reproduction in any medium, provided the original author and source are credited. 
area devoted to vegetable production and this contributed to the world watermelon production with $4.6 \%$ of 99,194,223 tonnes [4].

Watermelon seeds are good sources of vitamins; they are equivalent to multivitamin B complex supplement we consume [5]. Some of the vitamin B present in watermelon seed includes niacin, foliate, thiamine, riboflavin, vitamin B6 and pantothemic acid. Hundred grams (100gm) of watermelon seed provide $19 \%$ daily value of Niacin which is essential in maintaining the nervous system, digestive system and skin health [5]. In Asian and Middle eastern countries, watermelon seeds are collected, dried and roasted for eating; watermelon seeds are also used in making soups and other beneficial products like watermelon seed oil, watermelon seed tea and watermelon seed extracts [6]. When we think of health benefits of watermelon, we tend to ignore the health benefits of watermelon seeds. Thus, we might need to rethink spitting or discarding watermelon seeds. Relatively, little is known about the importance of watermelon seeds in Africa. A survey carried out in Benin indicates that watermelon seed may be more important as food source than previously anticipated [7]. From a nutritional point of view, the red and sweet watermelon seed is an important source of carotenoids including lycopine and B-carotene, a pre-cursor of Vitamin A [8],[9]. Water melon seeds and flesh are rich in citrulline which can be metabolized to arginine. The amino acid is a substrate for the synthesis of nitric oxide and it plays a role in cardiovascular and immune functions [10].

[11] defined marketing as the performance of all business activities that evolved into the forward flow of goods and services like water melon from the point of production to the hands of ultimate consumers. Marketing of water melon supplement in that it makes what is produced available to consumers and use the time, place and form required. [12] stated that within the market system, prices, allocation of resources, income distribution and capital formation are determined. Therefore, Marketing will have significant effects on the total production of a given commodity, on consumer price, on adoption of improve technology, in production and marketing methods and infact, upon the growth and development of the entire economy.

Based on this, it will be of interest to study the Profitability of water melon marketing in different parts of Kaduna Northern Guinea Savanna to broaden the understanding of the diversity within the plant, develop local conservation strategies and to identify the potential of the fruits and seeds to enhance food security, medicine, nutrition and income generation for the public.

\section{METHODOLOGY}

\subsection{STUDY AREA}

The study was conducted in selected markets in parts of Kaduna Northern Guinea Savannah of Nigeria. The markets sampled were selected in four (4) local governments, which are; Kaduna North, Kaduna South, Igabi and Chikun local government areas. Kaduna State is located North Western part of Nigeria along latitude $9^{0} 3^{1}$ and $11^{0}$ $32^{1} \mathrm{~N}$ and longitude $6^{0} 5^{1}$ and8 ${ }^{0} 4^{1} \mathrm{E}$ [13],[14]. It lies within the Guinea Savanna eco- region with mean annual rainfall of about $1239.5 \mathrm{~m}$. The temperature in the area is generally high especially during the dry season. It ranges between $25.5^{\circ} \mathrm{C}$ to $30^{\circ} \mathrm{C}[14]$.

\subsection{DATA COLLECTION}

A pre-survey of the parts of Kaduna Northern Guinea Savannah was conducted to identify major markets in each local government where water melon marketers are. One major market was chosen from each local government area. These markets are: Igabi (Mando Market); Kaduna North (Kawo Market); Kaduna South (Station Market) and Chikun (Buruku Market). Twenty-five (25) questionnaires were randomly administered in each of the market to make a total sum of one hundred questionnaires (100) in all. Fifty-one (51) were however retrieved.

\subsection{DATA ANALYSIS}

The following tools of analysis were used to analyze the data collected.

- Descriptive Statistic

- Gross Margin Analysis

International Journal of Research -GRANTHAALAYAH 
1) Descriptive Statistic: Descriptive statistic such as frequency, percentages were used to analyze some socio-economic characteristic known to influenced water melon marketers in Kaduna Northern Guinea Savannah of Nigeria.

2) Gross Margin Analysis: the gross margin analysis involves evaluating the efficiency of an individual enterprise so that the comparison can be made between enterprises of different farm plans [11].

$\mathrm{GM}=\mathrm{TR}-\mathrm{TVC}$

Where:

GM= Gross Margin (\#)

$\mathrm{TR}=$ Total Revenue (\#)

TVC=Total Variable Cost (\#)

However, Z- test was used to test the hypothesis formulated and is given as below;

$\mathrm{Z}=\mathrm{x} 1-\mathrm{x} 2$

$\sqrt{\frac{S_{1}^{2}}{N_{1}}+\frac{S_{2}^{2}}{N_{2}}}$

Where:

$\mathrm{X}_{1}=$ mean value of return from water melon Production

$\mathrm{X}_{2}=$ Mean value of cost from water melon marketing

$\mathrm{S}_{1}=$ Variance of return

$\mathrm{S}_{2}=$ Variance of cost from water melon production

$\mathrm{N}_{1}=$ Sampling size associated with returns

$\mathrm{N}_{2}=$ Sampling size associated with cost from water melon production

A positive gross margin would indicate the water melon marketing in the study area is profitable [11]

\section{Study Hypothesis:}

$\mathrm{H}_{0}$ : Water melon (Citrillus lanatus) production in Kaduna Northern Guinea Savanna is not profitable.

\section{RESULTS AND DISCUSSION}

Socio-economic characteristics of the sampled water melon marketers: Some socio-economic characteristics are known to influence water melon marketers in parts of Kaduna Northern Guinea Savannah of Nigeria. The variables analyzed in this study include: Age, Marital Status, Gender and Level of Education.

Table 1: Socio-economic Characteristics of the Respondents

\begin{tabular}{|l|l|l|}
\hline Variable & Respondents & Percentages \% \\
\hline Age in Years & & \\
$25-35$ & 19 & 37.25 \\
$35-45$ & 22 & 43.14 \\
$45-55$ & 10 & 19.61 \\
\hline Marital Status & & \\
Married & 37 & 72.55 \\
Single & 14 & 27.45 \\
\hline Gender & & \\
Male & 38 & 74.51 \\
Female & 13 & 25.49 \\
\hline Education Level & & \\
Tertiary & 20 & 32.21 \\
Secondary & 18 & 35.29 \\
Primary & 13 & 25.49 \\
\hline Total & 51 & 100 \\
\hline
\end{tabular}


Table 1 revealed that $43.14 \%$ of the sampled consumers were between the age brackets of $35-45$ years. This implies that they were at middle and economic age which could have positive effects on their standard of living. The age distribution of the respondents determines their productivity or managerial ability in any business enterprise. This is especially true in traditional society of Nigeria. This result agrees with the findings of [15], which shows that age influence the profitability in several ways. $72.55 \%$ of the sampled marketers were married, $74.51 \%$ were male and $25.49 \%$ were females. $32.21 \%$ of the sampled respondents had secondary education as $35.29 \%$ had tertiary education; the remaining $25.49 \%$ had primary education. This implies that all the sampled respondents were literate; they know how to read and write. [14] observed that formal education has a positive influence on marketing and profitability of goods.

Table 2: Average Gross Margin Analysis of Sampled Marketers

\begin{tabular}{|c|c|}
\hline Variables & Average Mean Cost \\
\hline Transportation & $3,350,230$ \\
Commission Cost & $1,300,250$ \\
Total Variable Cost & $4,650,480$ \\
Gross Income (\#) & $15,601,600$ \\
Net Income & $10,851.20$ \\
\hline
\end{tabular}

Table 2 revealed that gross margin is positive and profitable with estimated value of \#10,851.20. The calculated value was statistically significant at $(\mathrm{P}>0.05)$ level of probability. Thus, the null hypothesis $\left(\mathrm{H}_{0}\right)$ was rejected and alternative hypothesis $\left(\mathrm{H}_{1}\right)$ that water melon production in Kaduna Northern Guinea Savanna was profitable in the study area was accepted.

\section{CONCLUSION AND RECOMMENDATION}

The study has revealed that water melon marketing is profitable with an average net income of \#10,851.20. Based on these findings, the following recommendations are made:

1) There is need for effective government supported institutions such as entrepreneurial development units, co-operative bodies and other relevant institution under the State Ministry of Environment to motivate the water melon traders through adequate price support activities, loan and subsidies input.

2) Government should provide good road network for the production areas

3) The extension system in the area should be strengthened to enable farmers adopt not only improved water melon varieties but other water melon production technologies such as sowing, spacing, weed control, fertilizer application, pest and disease control and lastly,

4) The extension workers should organize workshop, seminars for the traders as appropriate

\section{SOURCES OF FUNDING}

None.

\section{CONFLICT OF INTEREST}

None.

\section{ACKNOWLEDGMENT}

None. 


\section{REFERENCES}

[1] Naz, A, Butt, M.S, Pasha, I and Nawaz, H (2013). Antioxidant Indices of Watermelon Juice and Lycopene Extract. Pakistan Journal of Nutrition 12 (3), 255-260

[2] Robinson, R.W. and Decker-Walters, D.S. (1997). Cucurbits. CAB International, Wallingford, United Kingdom. Pp 226.

[3] Jefferey, C (2001). Cucurbataceae. In Hanalt, P. (ed) Mansfeld's ornamentals. Published by Springer, Berlin, Germany., Vol.3: 1510 - 1557.

[4] FAO (2008). Food and Agricultural Organization of the United Nation (Database) HH:faostate.fao.org/site/567.

[5] Wasylikowa, K. and Vanderveen, M. (2004). An Archaeobotanical Contribution to the History of Watermelon, Citrullus lanatus (Thumb) Matsum \& Nakai (Syn.C. vulgaris Schred.). Veg. Hist. Archaeobot.,) .13: 213 - 217.

[6] Das, M., Das, S.K., and Suthar, S.H (2002) Composition of Seeds and Characteristics of Oil from Karingda (Citrullus lanatus (Thumb) Mansf). International Journal of Food Science and Technology37: 893 - 898.

[7] Achigan-Dako, E.G., Fagbamisi, R., Avohou, H.T., Vadouhe, R.S., Coulibaly, O. Ahance, A., (2009). Importance and Practices of Egusi Crops (Citrillus lanatus (Thumb.) Matsum \& Nakai, Cucumeropsis Manni, Nau"Aklamikpa" in Sociolinguistic Areas in Benin, Brotechnd.Agron.Soc.Environ12: 393 - 403.

[8] Setiawan, B., Suleiman, A., Giraud, D.W. and Driskel, J.A (2001). Carotenoid Content of Selected Indonesian Fruit. Journal of Food Compos. Anal14: 169-176.

[9] Edwards, A.J., Vinyard, B.T., Wiley, E.R., Brown, E.D., Collins, J.K., Perkins-Verzie, P., Baker, R.A., and Clevidence, B.A. (2003). Consumption of Watermelon Juice increases Plasma Concentration. Journal of Nutrition. 133: 1045 - 1050.

[10] Collins, J.K., Wu, G., Derkins-Veazie, P., Spears, K., Claypool, P.L., Baker, R.A. and Clevidence, B.A. (2007) Watermelon Consumption Increases Plasma Arginine dia and Lagamaria siceraria (Molina Standi.CV. Concentration in audits. Journal of Nutrition23: $261-266$.

[11] Olukosi, J. O, Isitor, S.U and Ode, M.O (2005). Introduction to Agricultural Economics Marketing and prices: Principles and Applications AGITAB Publishers, Zaria, Kaduna state, Nigeria. Pp 12.

[12] Olukosi, J.O and Isitor, S.U (1995). Introduction to Agricultural Economics Marketing and prices: Principles and Applications AGITAB Publishers, Zaria, Kaduna state, Nigeria. Pp 14.

[13] Akande, M.T, Akinyemi, O. Oladele, N.O and Sodimu, A.I (2009): Medicinal Values of Three Selected Plants in Kaduna Metropolis. International Journal of Botany. Vol.1(1):35

[14] Sodimu, A.I, Obadimu, O.0, Ojo, O.S., Jayeoba, W.A. (2012) Economic Analysis of Hibiscus sabdariffa Marketing in Kaduna Metropolis, Kaduna State. Proceedings of paper presented at 30th Conference of the Horticultural Society of Nigeria. pp 247- 249.

[15] Sodimu, A. I, Akinyemi, O, Adejoba, O, R. and Akande, M. T (2010). Constraints and Profitability of Modern Beekeeping Technology in Kudan Local Government Area of Kaduna State. African Journal of Agricultural Research and Development, Vol.3 Number 3 pp 7 -10. 